DOI: https://doi.org/10.32839/2304-5809/2020-4-80-91

UDC 347.7

Rza Mustafayev Vagif

Vytautas Magnus University

\title{
DIVIDEND PAYMENTS AS JUSTIFICATION FOR SHAREHOLDER PRIMACY
}

Summary. The article is meant to analyze the residual claimant position of shareholders from the perspective of dividend payments. It goes through the historic preconditions regarding the dividends which caused the enforcement of shareholder primacy rule. The study shows that traditional views regarding dividends fail to clearly justify shareholder primacy. It emphasizes the discretion of managers in the dividend payments and increasing number of companies which refrain from paying dividends despite their full capacity. As a conclusion, it reveals the incompatibility traditional view regarding dividend payments and shareholder primacy to modern-day reality.

Keywords: stakeholders, income, management, company, finance, fiduciary duty.

Tntroduction. Shareholder primacy has per1 meated corporate governance for a long period of time. The approach suggests that shareholders are the central parties to the governance and corporate agenda should be built upon their financial wellbeing. It also marginalizes the role of other stakeholders of the company labeling their claims as contractual and fixed in contrast to shareholder claims which are residual.

One of the old columns that shareholders' residual claimant position holds on is related to the payments of dividends. Conventional view claims that since shareholders receive their share in the profits the last, they are supposed to receive due heed by the corporate management.

A dividend can be defined as payment of profits by a company to its stockholders. This is the money left in the company after all business expenses and liabilities, including any taxes are paid. Usually the dividends are paid in annual or quarterly basis [5]. Occasionally they are mistaken with expenses of the company, but dividends are just a mechanism through which the profits are distributed to the stockholders [6].

Mainly dividends are paid in form of cash, rarely in form of stocks or other property. There are four important dates in the procedure of the dividend payment that both shareholders and managers follow. They are date of declaration, date of record, ex-dividend date, and date of payment. The declaration date is the date when the directors of the company informs that a dividend will be paid. The announcements are mainly done through financial press or elsewhere. Meanwhile, the directors declare record date which sets the list of shareholders that will get the dividends. The investors that acquire the shares after this date has gone ex-dividend and are do not have the right to receive the dividend since there is not enough time to get their purchases on the books before the date of record and the dividend payment. The date payable is the date when the dividends are distributed [3].

Research object: Theoretical and statistical data and case studies concerning the corporate governance and finance.

Research aim: The study is aimed to analyze dividend payments as a justification for shareholder primacy.

\section{Research objectives:}

1. Analyzing the history behind dividend payments.
2. Determining modern trends in dividend payments.

3. Revealing contemporary connection between shareholder primacy and dividend payments.

Dividend payments and shareholders' claim. The history of corporate dividends is not a product of modern-day corporate law and is closely related to the evolution of the corporate form itself. First corporate dividends in a simple version were used in the early 16th century in Holland and Great Britain. Back then the captains of $16^{\text {th }}$ century trade ships commenced selling financial claims to the investors. Those claims entitled investors to have a share in the possible profits of the journey. When the voyage ended, the venture was liquidated and claims of investors to profits and the capital were fulfilled. In the end of the 16th century, the financial claims started to be traded on the open markets in Amsterdam. With passage of time they were gradually replaced with ordinary shares as we know today. It is necessary to note that even then most of the investors used to buy shares from different captains in order to diversify the risk related to this form of business [7]. The liquidation of the enterprise when the journey ended serves as guarantee for the handling of the profits to shareholders and contributed in reduction of the chances of fraudulent acts by the captains. Nevertheless, since the profitability of the ventures was firm more regular with the passage of time, the liquidation process of the assets at the end of each journey became unnecessarily disruptive and expensive. The profitability of the voyages raised their credibility, consequently shareholders tended to be more confident in captains. The tendency was accelerated by high dividends paid to the shareholders [9]. As a consequence, these ventures started to trade as a long-term and steady entities, conveying solely the profits instead of the whole capital which was invested. In the beginning of the history of corporate form, managers understood the significance of generous and ongoing dividend distributions. To some extent, such trend can be related to the parallels investors drew between dividends and the other type of financial security traded at that time, namely state bonds. Bonds were paying a proper and steady interest payment, thus corporate managers realized that investors would choose shares that were similar to bonds. For instance, Bank of North America in 1781 distributed profits to its shareholders after only six months of 
the establishment, and the bank charter entitled the board of directors to distribute dividends regularly out of profits [7]. As it is seen, dividends were regarded as an important way of increasing the attractiveness of the firm and demonstrating its success. Beyond the significance dividend stability for the shareholders, additional idea of contemporary corporate dividend policy that emerged in the early $19^{\text {th }}$ century was that dividends were considered as an important source of information about the company. The insufficiency and lack of credibility of financial information paved the way to investors making their conclusions about the companies by their dividend distributions instead of publicly available reported earnings. In other words, potential investors frequently facing the insufficient information related to the performance of the company, used its dividend policy in order to understand current financial health of the firm and predict its future development. As an outcome, an escalation in divided distribution was inclined to be reflected in increasing stock prices. As companies were getting acquainted with this tendency, it positively affected the opportunity that managers were able to use dividends to inform about prospective earnings and/or to uphold the company's share price since the investors can see dividend announcements as a proof of earnings increase.

To sum up, the evolution of dividend distribution to stockholders has been related to the evolution of the corporate form itself. Managers regarded high levels of dividend payments as an efficient way of fulfilling shareholder expectations. They frequently increased and made every effort to sustain dividends over time asserting that dividend cuts can negatively affect share prices and consequently, utilized dividends as a medium to signal data to the market. However, since the 1950's, the impact of dividend policy on firm value was tensely questioned by many corporate scholars [7]. One of the modern approaches to the question whether dividend policy has an effect on share prices is dividend irrelevance theory. The theory suggests that dividends have little or no effect on the share prices [8].

The general rule suggests that after all legal and contractual claims are fulfilled sharehold- ers are entitled to the residual profits made by the company. The suggestion strongly rejected by a famous American Corporate Law scholar Lynn A. Stout. The superior position of shareholder interests backed by their residual claims was called to be "appealing", but "wrong" [14].

Firstly, the decision to pay dividends is at full discretion of the board of directors. "It is essential to recognize that neither contingency is met unless the board of directors wants it to be" [14]. This is supposed to mean that the final decision to pay dividends is made by managers. The earnings made by the company can be spent on new investments or improvement of work conditions. It is more likely that the company will reinvest the profits made for expansion of the service area, promotion of its trademarks and so forth. The directors can also decide to have the option of increasing executives' salaries, start an on-site childcare center, create a quality customer service, provide retirement benefits, and make corporate charitable payments.

"Even if a corporation is drowning in a flood of money, it remains up to the directors to decide whether and to what extent shareholders will share in the wealth through either dividends or share price appreciation. This is because directors control dividends under the dividend rules and control earnings under the accounting rules. Earnings are nothing more than revenues minus expenses-and it is the directors, and not the shareholders, who determine the corporation's expenses" [16].

Decision to pay dividends is regarded by managers as serious responsibility. Once decided to distribute profit to shareholders, company cannot uneventfully undo it. Ceasing to pay dividends or reducing them can be seen as negative signal by some investors [1]. Modern trends openly demonstrate that profit distribution in form of dividends is of decreasing popularity. More and more companies prefer to preserve the profits in the company and re-invest it. Data collected from 1990 to 2010 which includes listed firms from 21 European countries explicitly demonstrate this ongoing process [17].

Generous profit distribution is not something that some S\&P 500 companies prefer to stand out. Famous to everyone companies such as Facebook,

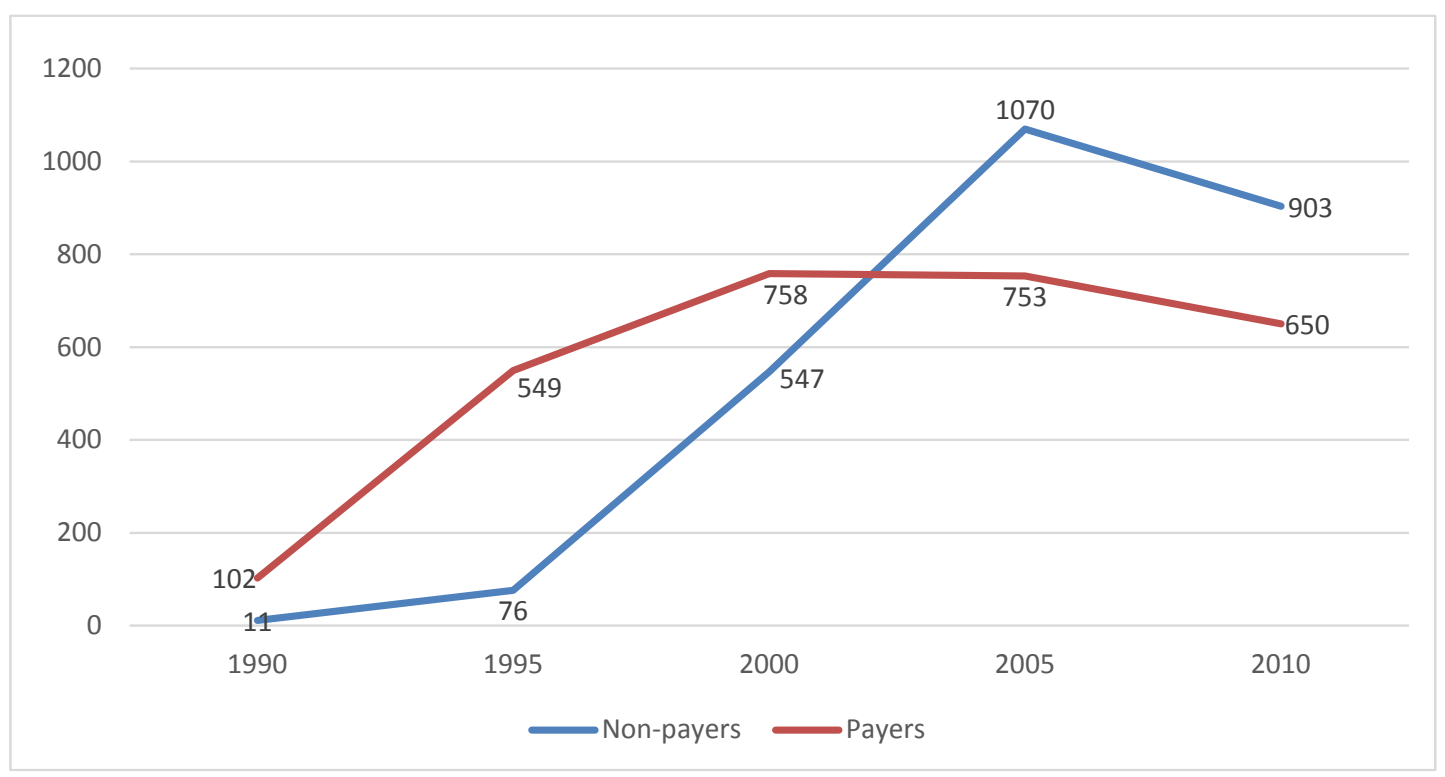


Adobe Systems Inc., Autodesk Inc., Amazon.Com Inc., Biogen Inc., Electronic Arts Inc., Ebay Inc., Netflix Inc., Paypal Holdings, Tripadvisor Inc. do not pay dividends. Some of them, despite having average sales increase over the last five years exceeding $10 \%$, debt-to-equity ratio being one, profit margin exceeding $20 \%$ still do not pay dividends [19]. The company here that provokes interest here is Facebook with a market capitalization of $\$ 522$ billion owning Instagram, WhatsApp, and Messenger. From its establishment the company has never paid dividends to its shareholders [2].

A research studying a decreasing pattern in dividend payments in Canada reveals several major reasons for not-paying or cutting dividends.

"Preference to reinvest cash flows instead of paying dividends

Stage in the firm's life cycle

Availability of cash level of current earnings

Availability of profitable investment opportunities

Anticipated level of future earnings

Cost of raising external funds

Concern about maintaining a target capital structure

Desire to conform to industry dividend practice" [11]

Moreover, the dividends cannot be distributed to shareholders unless the company has distributable profits and payment of dividends would not cause the cause the equity capital of the firm to be lower than aggregate amount of the capital of the company. Such view is generally accepted by many countries whether it is an EU (Lithuania [12]) or a Non-EU country (Azerbaijan [4]). Such approach finds support also in case law. Thus, in re Exchange Banking Company or Flitcroft's case (1882), where the shareholders were intentionally paid dividends from accounts full of debts and irrevocables, the directors were held liable for the distributed money [18].

The treatment of shareholders as residual claimants has its roots in bankruptcy law and making shareholders of healthy company to the shareholders of bankrupt company is misleading. The insolvent company is the only case where shareholders can be seen as residual claimants [13]. There are, however, some scholars questioning even this position [15].

One would argue that by not paying dividends the firm actually favors the financial interests of shareholders, since new investments and new prospects positively affect the share prices. Proponents of such view claim that the contingency of dividend payments does not affect the status of shareholders as residual claimants [10]. The approach cannot be fully disregarded. However, such profit is indirect and still is on discretion and performance of the directors.

As it was seen, assumption based on the condition that shareholders get dividends only after other contractual claims are fulfilled is not flawless. An increasing number of companies prefer not to distribute profit to shareholders in form of dividends. Legal restriction on dividend payments do exist. It is a wrong assumption to regard shareholders as sole residual claimants of the company. In fact, as the study will reveal they are only one of the many residual claimants of the firm standing on line with employees, customers, suppliers, creditors and so forth.

Conclusion. It was shown that the payment of the dividends which is one of the main reasons why shareholder are regarded as residual claimants does not support this idea. Despite the general rule that dividends are paid only after all contractual claims are satisfied, the argument was proved to be wrongly mirroring modern realities.

As was shown in data acguaired from different countries more and more companies, including many famous participants of S\&P500, are inclined to preserve the profits for future investments or other costs. Thus, it is in the discretion of the managers to distribute dividends to shareholders and no law actually obliges them for the opposite.

\section{References:}

1. Amy Fontinelle (2019). "Why Do Some Companies Pay a Dividend, While Others Don't?" Investopedia. Investopedia. September 11, 2019. Accessed September 21, 2019: https://www.investopedia.com/ask/answers/12/ why-do-some-companies-pay-a-dividend.asp

2. Bob Ciura (2019). "Will Facebook Ever Pay A Dividend?" Sure Dividend. May 21, 2019. Accessed September 21, 2019: https://www.suredividend.com/facebook-dividend/

3. Chand Smriti. "What Are the Procedures for Dividend Payment?" Your Article Library. February 24, 2014. Accessed September 18, 2019: http://www.yourarticlelibrary.com/economics/what-are-the-procedures-for-dividend-payment/1551

4. Civil Code of Azerbaijan Republic, s. 106-3.9: http://www.e-qanun.az/code/8, December 28, 2019.

5. "Dividends: How Do Dividends Work?" (2019). Accessed September 18, 2019: https://informi.co.uk/businessadministration/dividends

6. "Dividends: They Are Not an Expense!" (2017). Instafilesandbox. Company Accounts \& Tax Filing in Minutes / United Kingdom / Instafile. November 26, 2017. Accessed September 18, 2019: https://www.instafile.co.uk/singlepost/2017/11/26/Dividends-they-are-not-an-expense

7. Husam Al-Malkawi, -Aldin \& Rafferty, Michael \& Pillai, Rekha (2010). Dividend Policy: A Review of Theories and Empirical Evidence. International Bulletin of Business Administration. 9. 171-200.

8. James Chen. "Dividend Irrelevance Theory." Investopedia. Investopedia, January 31, 2019. Accessed September 21, 2019: https://www.investopedia.com/terms/d/dividendirrelevance.asp

9. Jonathan B. Baskin (1988). The Development of Corporate Financial Markets in Britain and the United States, 1600-1914: Overcoming Asymmetric Information, The Business History Review 62, 199-237.

10. Julian Velasco. Shareholder Ownership and Primacy (September 26, 2008). University of Illinois Law Review, Vol. 2010, No. 3, pp. 897-956.; Notre Dame Legal Studies Paper No. 08-31. Accessed September 25, 2019. Available at SSRN: https://ssrn.com/abstract=1274244 or http://dx.doi.org/10.2139/ssrn.1274244

11. Kent H. Baker and Chang, Bin and Dutta, Shantanu and Saadi, Samir, Why Firms Do Not Pay Dividends: The Canadian Experience (November/December 2012). Journal of Business Finance \& Accounting, Vol. 39, Issue 9-10, pp. 1330-1356, 2012. Accessed September 21, 2019. Available at SSRN: https://ssrn.com/abstract=2199730 or http://dx.doi.org/10.1111/jbfa.12005

12. Law on companies, Republic of Lithuania, s. 59.6, July 13, 2000 No VIII-1835: https://e-seimas.lrs.lt/portal/ legalAct/lt/TAD/2af0c0d049b811e68f45bcf65e0a17ee?jfwid=rivwzvpvg 
13. Lynn A. Stout. Bad and Not-so-Bad Arguments for Shareholder Primacy. Southern California Law Review, Vol. 75, p. 1189, 2002. Accessed September 24, 2019. Available at SSRN: https://ssrn.com/abstract=331464 or http://dx.doi.org/10.2139/ssrn.331464

14. Lynn A. Stout. The Shareholder Value Myth: How Putting Shareholders First Harms Investors, Corporations, and the Public. San Francisco: Berrett-Koehler, 2013.

15. Lynn M. LoPucki. The Myth of the Residual Owner: An Empirical Study (April 29, 2003). UCLA School of Law, Law \& Econ Research Paper No. 3-11. Accessed September 25, 2019. Available at: SSRN: https://ssrn.com/ abstract $=401160$ or http://dx.doi.org/10.2139/ssrn.401160

16. Margaret M. Blair and Lynn A Stout. "Specific Investment: Explaining Anomalies in Corporate Law" (2006). Cornell Law Faculty Publications. 767. Accessed September 21, 2019: https://scholarship.law.cornell.edu/facpub/767

17. Omar Meharzi, Ali Gohar, and Ali Ijaz. "Why do Firms Change Their Dividend Policy?" International Journal of Economics and Financial Issues, 2017, 7(3), 411-422. Accessed September 21, 2019. Available at: https://www.econjournals.com/index.php/ijefi/article/download/4341/pdf

18. 'Re Exchange Banking Co' on Revolvy.com.” n.d. Revolvy. Accessed September 24, 2019: https://www.revolvy.com/ page/Re-Exchange-Banking-Co

19. Stoyan Bojinov (2014). "S\&P 500 Companies That Don't Pay Dividends." Dividend.com. December 16, 2014. Accessed September 21, 2019: https://www.dividend.com/investor-resources/sp-500-companies-that-dont-pay-dividends/ 